\title{
2014 IEEE International Conference on Optical MEMS and Nanophotonics (OMN2014) 国際会議報告
}

\author{
佐々木 実（豊田工業大学）
}

\section{1. はじめに}

今年は 8 月 $17 \sim 21$ 日, イギリススコットランド, グラス ゴーの Strathclyde 大学にて開催された。避暑地として知 られているようで, 涼しかった（日本と比較すると，寒い に近い)。また，美味しいレストランもあった。

発表は, 基調講演 3 , 招待講演 8, 一般論文 100 (口頭 50, ポスター 50，採択率 95\%）件であった。国別では，日本が 29 件と貢献しており, アメリカ 14 , イギリス 13 , 台湾 12 , シンガポール 7 , ドイツ 6 , フランスと韓国が 4 ずつ, と続く。

\section{2. 会議の概要}

光ファイバ関係の研究で実績を誇る Southampton 大の Payne 氏が初日の基調講演を行った。エルビウム添加光ファ イバ増幅器 (EDFA) の発明で知られる。増幅可能な波長帯 域がファイバの低損失波長帯域と一致していた点で技術の 素性が良かった。光ファイバの損失は, 短波長側は Rayleigh 散乱, 長波長側は赤外吸収で決まる。総和の全損失が最小 となる波長が $1.55 \mu \mathrm{m}$ で, 光通信波長の代表值となってい る。研究が進んでいる光結晶ファイバでは, 主たる媒質が ガラスから空気に替わる。このため，特に長波長側の損失 が減り，最小損失の波長が約 $2.0 \mu \mathrm{m}$ になる。 $2.0 \mu \mathrm{m}$ 帯の増 幅器を材料変更により実現しているようである。また，一本 のファイバからの種光を, 並列接続した 64 個のアンプでコ ヒーレント増幅し, 集光することで大出力を得るプロジェ クトが紹介された。

招待講演にて, 香港理工大学からホローコアファイバを 使ったセンサが紹介された。ホローに測定対象ガスが入れ ば，長距離にわたって伝搬光と吸収等の相互作用を生じる。 $10 \mathrm{~m}$ 長でアセトン $1 \mathrm{ppm}$ を検出した。ガス拡散による時間 応答に時間がかかる問題は，フェムト秒レーザで穴を開け ることで 2 分程度に短くした。また，クラッドを薄くする など外圧を受けやすくして，音響センサにした例も示した。

基調講演にて NTT 基礎研究所の納富氏から光結晶関連の 研究が紹介された。電子デバイスでは情報コストを fJ/bit 程度にする動きがある。情報転送コストも同程度である心゙ きとの認識から，通信コスト fJ/bit 以下を目標に置く。ま た，従来型光デバイスを集積化すると配線での損失が大き くなることからフットプリント $10 \mu \mathrm{m}^{2}$ 以下も目標とする。 光結晶はこれらに答える。単一素子だけでなく, アレイ化 や異種機能の集積化が印象的であった。

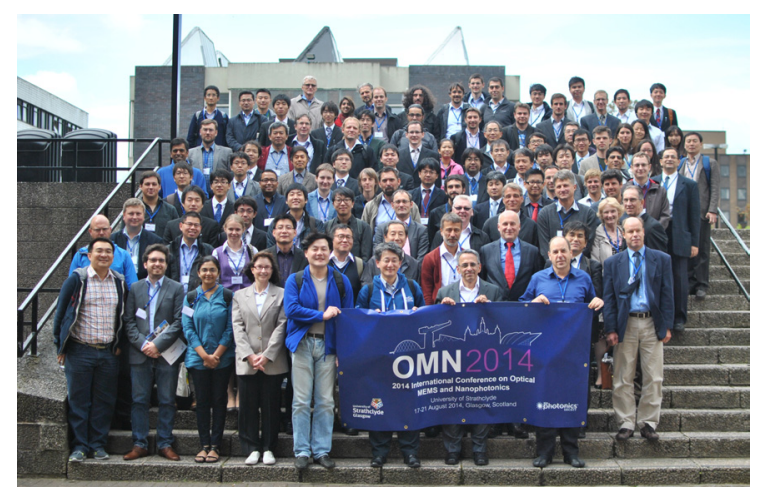

図 1 集合写真（最前列で旗を持つ中央の小柄の方が Deepak 議長，右が次回議長の Dan 氏）

招待講演にて Texas 大（旧 Illinois 大）の Coleman 氏は MOCVD 成長 InGaAs 材料を紹介した。成長途中のエッチ ングと選択成長を組み合わせ，規則的に並んだ $50 \mathrm{~nm}$ 以下 のナノポアを形成する。ユニットセル間の結合が強く表れ, エネルギーバンドを形成する。蛍光スペクトルは幅 $30 \mathrm{~nm}$ 程度の, 量子井戸の $50 \mathrm{~nm}$ 程度よりも狭く単一のピークを 示した。氏は EDFA ポンプレーザ用の成膜で知られる。

国立シンガポール大の Zhou 氏は, Alvarez 型の可変焦点 レンズを発表した。湾曲立体形状を持つ屈折素子のペアを 重ね, 光軸垂直方向にずらすことでレンズ焦点距離を可変 にする。 $\mathrm{Al}$ 材を Electric Discharge Machining で加工し PDMS 屈折素子に転写した。市販 PZT 素子に変位拡大機構 を組み合わせたアクチュエータ（片側で約 $90 \mu \mathrm{m}$ 変位）に 固定し，4 素子をアライメントした。0 から $130 \mathrm{~V}$ 印加で焦 点距離は 32 から $15 \mathrm{~mm}$ に変化した。素子間のアライメン 卜精度が現在の問題とのことである。

スタンレー電気と東大のグループから，ピエゾ駆動型マ イクロミラーが発表された。水平軸が共振で機械角 $\pm 12^{\circ}$ $25 \mathrm{kHz}$, 垂直軸が $\pm 8^{\circ} 60 \mathrm{~Hz}$ である。動的ミラーたわみを 減らすためにミラー裏面のリム構造を工夫し, ミラー根本の 応力解析とともにピエゾ素子の回転角センサを形成した。

\section{3. おわりに}

光通信の需要が着実に増えているようで, 光通信関係の 話題が印象に残った会であった。図 1 は 3 日目の昼食後に, 天候に恵まれたタイミングで撮った写真である。来年は 8 月 2～6 日に聖地エルサレムにて開催予定である。

(平成 26 年 9 月 16 日受付) 